\title{
DICHLOROACETATE-INDUCED NEUROPATHY IN HIGH GRADE FOLLICULAR LYMPHOMA PATIENT
}

\author{
Mladen Djordjević1, Ivan Petković2
}

\begin{abstract}
Curative therapy for follicular lymphomas (FLs) has not been established yet. FLs respond well to chemotherapy and radiation. A large number of current studies confirmed an improved overall response if rituximab was added to chemotherapy. Dichloroacetate (DCA) can be used to inhibit tumor growth. There have been reports that DCA leads to neuropathy. In non-Hodgkin's lymphoma (NHL), DCA leads to antineoplastic action against cell lines and apoptosis of tumor cells, which reduces the metabolism and the number of tumor cells. We present a patient with NHL-FL Grade 3a who took alternatively DCA therapy. In our case report, DCA did not show any treatment benefit but only serious sensorimotor neuropathy as a result of DCA therapy.
\end{abstract}

Acta Medica Medianae 2019;58(1):102-105.

Key words: follicular lymphoma, dichloroacetate, neuropathy

${ }^{1}$ Clinic of Oncology, Department for Hematooncology, Clinical Center Niš, Serbia

2University of Niš, Faculty of Medicine, Niš, Serbia

Contact: Mladen Djordjević

Branka Krsmanovića 4/74, 18000 Niš, Serbia

E-mail: mladen.djordjevic555@gmail.com

\section{Introduction}

Follicular lymphomas (FLs) are the second most frequent subtype of nodal lymphoid malignancies in Western Europe. The annual incidence of this disease has rapidly increased during recent decades and has risen from $2-3 / 100,000$ during the 1950 s to $5 /$ 100,000 recently (1).

Curative therapy for FLs has not been established yet. The choice of therapy is based on clinical risk factors, symptoms and prognostic disease factors. Systemic therapy has not given results in asymptomatic patients and is appropriate for use only with the occurrence of symptomatic disease. Early initiation of rituximab $(R)$ resulted in improved progression-free survival, but without survival benefit. FLs respond well to chemotherapy and radiation. A large number of current studies confirmed an improved overall response if rituximab was added to chemotherapy. The choice of chemotherapy is based on patient comorbidity indexes, mostly in the light of anthracycline introduction (2).

Dichloroacetate (DCA) has been used for the genetic mitochondrial diseases and treatment of cancer. There have been reports that DCA leads to neuropathy (3). DCA can be used to inhibit tumor growth. This is done by transferring the cell into oxidation and phosphorylation into mitochondria, which lead to apoptosis and the formation of oxygen radicals, superoxide, that also lead to a decrease in tumor volume (4). The mechanism of DCA action includes the inhibition of pyruvate dehydrogenase kinase (PDK), which deactivates the PDK complex. This complex blocks the activity of mitochondria, and therefore there is no mitochondrial oxidative phosphorylation, so that glycolysis is switched into cytoplasm, which leads to lactic acidosis (5). Lactic acidosis facilitates tumor growth by the degradation of an extracellular matrix that allows expansion of tumor cells and initiates their mobility, increasing their metastatic potential and activation of angiogenesis. DCA reduces lactic acidosis and indirectly reduces tumor growth (6). When the mitochondria in the tumor cell are active, it means that they are having the Krebs cycle or glucose oxidation. Being hyperpolarized, they open the mitochondrial pores from which exit cytochrome $\mathrm{C}$ and other pro-apoptotic factors that caused tumor cell apoptosis (7).

In non-Hodgkin's lymphoma (NHL), DCA causes antineoplastic action against cell lines and apoptosis of tumor cells, which reduces the metabolism and the number of tumor cells. A decrease in lactic acidosis in lymphoma cells leads to anti-proliferative, antimetastatic and anti-angiogenic effects on the tumor. DCA causes a significant dose-dependent decline in tumor cell survival. DCA induces dose-dependent apoptosis in Dalton's lymphoma (DL) cells $(8,9)$. 


\section{Case report}

We present a case of a 44-year-old Caucasion male with asymptomatic swollen lymph nodes of the neck and under the jaw. In June 2014, he noticed enlarged tonsils and vegetative-infiltrative tumor of the right tonsils was verified by examination. Bilateral tonsillectomy was performed in June 2014 with the right lateral lymph node biopsy. Histopathology indicated NHL-FL Grade 3a. Immunohistochemistry was typical: CD20+, CD79a+, BSAP (PAX5)+, CD10+, bcl2+, bcl6+, CD43+/-, MUM1-, CD3-, CD5, CD15-, CD23-, CD30-, CD138-, CyclinD1-, EMA-, CK AE1/AE3-, EBV -, Ki67+ in range of $20 \%-25 \%$. The patient did not have $B$ symptoms. During the staging procedures, the following was verified: ECOG 0 KI 100. Multi-sliced computed tomography (MSCT) of the whole body was performed and it revealed: microlimphadenopathy of the right axillary lymph nodes up to $12 \mathrm{~mm}$. Laboratory analysis: erythrocyte sedimentation - 15, Hct 38.1\% (low), Hb 124g/ L, RBC 4.17X 1012/L, WBC 4.7 X 109/L, Neu 2.9 X $10^{9} /$ L, Ly $1.3 \times 10^{9} / \mathrm{L}$, PLT $283 \times 10^{9} / \mathrm{L}$. Biochemistry findings: glucose $5.4 \mathrm{mmol} / \mathrm{L}$, urea $3.5 \mathrm{mmol} / \mathrm{L}$, creatinine $102 \mu \mathrm{mol} / \mathrm{L}$, uric acid $330.3 \mu \mathrm{mol} / \mathrm{L}$, total proteins $73.9 \mathrm{~g} / \mathrm{L}$, albumine $42.9 \mathrm{~g} / \mathrm{L}$, AST $18 \mathrm{U} / \mathrm{L}$, ALT 21 U/L, ALP 104.8 U/L, LDH 322 U/L, GGT 17.7 $\mathrm{U} / \mathrm{L}, \mathrm{CRP} 1.5 \mathrm{mg} / \mathrm{L}$, total bilirubin $10 \mu \mathrm{mol} / \mathrm{L}$, Fe 12.7 $\mu \mathrm{mol} / \mathrm{L}$, Ca $2.72 \mathrm{mmol} / \mathrm{L}, \mathrm{Na} 141 \mathrm{mmol} / \mathrm{L}, \mathrm{K} 4.8$ $\mathrm{mmol} / \mathrm{L}$. He was HIV, HCV, HBsAg negative. Plasma immunoglobulins: IgG $10.50 \mathrm{~g} / \mathrm{L}, \mathrm{IgM} 0.97 \mathrm{~g} / \mathrm{L}, \mathrm{IgA}$ $2.32 \mathrm{~g} / \mathrm{L}, \beta 2$ microglobuline $2.15 \mathrm{mg} / \mathrm{L}$. In electrophoresis, alpha 2 fraction was elevated without pathological defects, no $\mathrm{M}$ component was found in plasma. The bone marrow biopsy showed no infiltration of lymphoma cells. The disease was staged as minimum II CS A, with Follicular Lymphoma Internatio nal Prognostic Index (FLIPI) -0, FLIPI 2-1. Because of asymptomatic FLs, low Ki67 fraction and good prognosis index, chemoimmunotherapy was not implemented. Positron emission tomography combined with CT (PET/CT) found no pathological uptake of 18 Fluoro-deoxy-glucose (18FDG). He underwent "watch and wait" strategy and follow-up. The patient started to take DCA on his own initiative. He was taking DCA for 9 months in the dose range of $750 \mathrm{mg}$ with thiamine. There were no effects on lymph node size; moreover, they were enlarged during the follow-up visits. The patient was still in an asymptomatic phase and deserved no treatment initiation. However, toxic neuropathic effects on his ex-tremities occurred over time and became more and more serious. This finding was confirmed by electro-neurography and staged as grade 3 neuropathy of sensorimotor conduction. The patient ceased further DCA intake after obtaining medical advice. He is now recovering from the negative side effects of DCA and is still under the strict neurologic observation.

\section{Discussion}

Nowadays, DCA in NHL therapy is especially used in experimental preclinical studies and as an alternative therapy based on the DCA mechanism effect on NHL tumor cells. We already know that nerve toxicity is more frequent in adulthood than in children. DCA has been used only as an alternative to official oncology therapy.

There have been reports on the level of case reports only, which demonstrated a successful treatment of NHL with DCA. Flavin D published a report on a patient with NHL treated successfully with R-cyclophosphamide, doxorubicin, vincristine and prednisone (CHOP) over 3 months with PET/CT, showing a complete remission of the disease. However, relapse occurred almost a year after treatment. The patient was obtaining $10 \mathrm{mg} / \mathrm{kg}$ daily of DCA, with the addition of $750 \mathrm{mg}$ of thiamine daily as a neuroprotective agent from DCA toxicity. After four months of DCA intake, PET/CT showed complete remission of NHL. However, this single observation was not associated with any follow-up period (10).

Other case report published by Strum SB et al. presented a patient with $\mathrm{NHL}$ who received $\mathrm{R}$ CHOP therapy as well, which led to complete remission. A year after, the symptoms returned and PET/ CT showed a disease relapse. The patient took DCA therapy: 1,000 $\mathrm{mg}$ per day in one daily dose, $55 \mathrm{mg}$ of caffeine and vitamin B1 $500 \mathrm{mg} / \mathrm{d}$. One month after the initiation of the DCA protocol, the neck lymph nodes were noticeably smaller and after 2 months no nodes were palpable. Complete resolution of all systemic symptoms disappeared after 71 days of DCA protocol. The patient had reversible neuropathy and encephalopathy during DCA course which did not reverse entirely in spite of taking a neuroprotective agent. This report highlighted the low cost and minimal toxicity of DCA (11).

There were many studies where treatment with DCA has been discontinued despite the fact that thiamine was used as a prevention of nerve toxicity. DCA leads to encephalopathy and peripheral neuropathy. In Brandsma D et al.'s case report it was noticed that DCA encephalopathy and peripheral neuropathy were reversible but not entirely because small consequences remained, although the patient took the recommended dose range of thiamine. Due to the apparent toxicity of DCA, it is recommended to use it only in clinical trials. Peripheral neuropathy was more common in adults (86\%) than in children (10\%) (12). DCA damage the Schwann cells (SCs) and dorsal root ganglia (DRG) neurons by inhibiting the synthesis of myelin. As a consequence of DCA's direct action on the morphology of SC cells, there is an evidence-based and dose-dependent change in morphology. The partial recovery of myelination was noticed when exposed to $5 \mathrm{mM}$ of DCA under the same conditions. Also, myelination was completely reversible in SC and neurons of DRG (13).

Our patient had DCA intake in the dose range of $750 \mathrm{mg}$ with thiamine neuroprotection. However, his lymph nodes have enlarged slightly. During the follow-up, the patient remained still asymptomatic. We assume this asymptomatic phase is the consequence of natural biological flow of FL and is not influenced by DCA. We have only found serious sensorimotor neuropathy as a result of DCA therapy. 
In conclusion, our case presented here did not show any treatment benefit with DCA, but only serious adverse event in the sense of neuropathy. There- fore, this case provides information to medical community on the negative consequences of DCA treatment for NHL.

\section{References}

1. Mounier M, Bossard N, Remontet L, Belot A, Minicozzi $P$, De Angelis $R$, et al. Changes in dynamics of excess mortality rates and net survival after diagnosis of follicular lymphoma or diffuse large B-cell lymphoma: comparison between European population-based data (EUROCARE-5). Lancet Haematol 2015; 2(11): e48191. [CrossRef] [PubMed]

2. Dreyling $M$, Ghielmini $M$, Rule $S$, Salles $G$, Vitolo $U$, Ladetto M; ESMO Guidelines Committee. Newly diagnosed and relapsed follicular lymphoma: ESMO Clinical Practice Guidelines for diagnosis, treatment and follow-up. Ann Oncol 2016; 27(5):v83-v90.

[CrossRef] [PubMed]

3. Kagiava A, Theophilidis G. High concentrations of dichloroacetate have minor effects on the vitality of the mammalian nerve fibers: an ex-vivo electrophysiological study. Anti-cancer Drug 2011; 22(3):27366. [CrossRef] [PubMed]

4. Bonnet $S$, Archer SL, Allalunis-Turner J, Haromy A, Beaulieu C, Thompson $\mathrm{R}$, et al. A mitochondria-K+ channel axis is suppressed in cancer and its normalization promotes apoptosis and inhibits cancer growth. Cancer Cell 2007; 11(1):37-51. [CrossRef] [PubMed]

5. Calcutt NA, Lopez VL, Bautista AD, Mizisin LM, Torres $B R$, Shroads $A L$, et al. Peripheral neuropathy in rats exposed to dichloroacetate. J Neuropath Exp Neur 2009; 68(9):985-93. [CrossRef] [PubMed]

6. Michelakis ED, Webster L, Mackey JR. Dichloroacetate (DCA) as a potential metabolic targeting therapy for cancer. Brit J Cancer 2008; 99(7):989-94. [CrossRef] [PubMed]

7. Halestrap A. Biochemistry: a pore way to die. Nature 2005; 434(7033):578-9. [CrossRef] [PubMed]
8. Kumar A, Kant S, Singh SM. Novel molecular mechanisms of antitumor action of dichloroacetate against $T$ cell lymphoma: Implication of altered glucose metabolism, $\mathrm{pH}$ homeostasis and cell survival regulation. Chem-Biol Interact 2012; 199(1):29-37.

[CrossRef] [PubMed]

9. Kumar A, Kant S, Singh SM. Antitumor and chemosensitizing action of dichloroacetate implicates modulation of tumor microenvironment: a role of reorganized glucose metabolism, cell survival regulation and macrophage differentiation. Toxicol Appl Pharm 2013; 273(1):196-208. [CrossRef] [PubMed]

10. Flavin DF. Non Hodgkin's lymphoma reversal with dichloroacetate. J Oncol 2010; 2010:414726. [CrossRef] [PubMed]

11. Strum SB, Adalsteinsson O, Black RR, Segal D, Peress NL, Waldenfels J. Case Report: Sodium dichloroacetate (DCA) inhibition of the "Warburg Effect" in a human cancer patient: complete response in nonHodgkin's lymphoma after disease progression with rituximab-CHOP. J Bioenerg Biomembr 2013; 45(3): 307-15. [CrossRef] [PubMed]

12. Brandsma D, Dorlo TP, Haanen JH, Beijnen JH, Boogerd $W$. Severe encephalopathy and polyneuropathy induced by dichloroacetate. J Neurol 2010; 257 (12): 2099-100. [CrossRef] [PubMed]

13. Felitsyn N, Stacpoole PW, Notterpek L. Dichloroacetate causes reversible demyelination in vitro: potential mechanism for its neuropathic effect. J Neurochem 2007; 100(2):429-36. [CrossRef] [PubMed] 


\title{
NEUROPATIJA IZAZVANA DIHLOROACETATOM KOD BOLESNIKA SA FOLIKULARNIM LIMFOMOM VISOKOG GRADUSA
}

\author{
Mladen Đorđević ${ }^{1}$ Ivan Petković2 \\ ${ }^{1}$ Klinika za onkologiju, Odsek za hematoonkologiju, Klinički centar Niš, Srbija \\ ¿Univerzitet u Nišu, Medicinski fakultet, Niš, Srbija \\ Kontakt: Mladen Đorđević \\ Branka Krsmanovića 4/74, 18000 Niš, Srbija \\ E-mail: mladen.djordjevic555@gmail.com
}

Kurativna terapija folikularnog limfoma (FLs) još uvek nije uspostavljena. Fls odlično reaguje na hemoterapiju i radioterapiju. Veliki broj sadašnjih studija potvrdio je bolji ukupni odgovor ako se rituximab koristi uz hemoterapiju. Dihloracetat (DCA) može biti korišćen zbog inhibicije tumorskog rasta. Postoje izveštaji da DCA dovodi do neuropatije. U ne-Hočkinskom limfomu (NHL) DCA dovodi do antineoplastičkog efekta ćelijskih linija i apoptoze tumorskih ćelija, što smanjuje metabolizam i broj tumorskih ćelija. Mi predstavljamo bolesnika sa NHLFL gradusa za koji je uzimao DCA kao alternativnu terapiju. U našem prikazu slučaja DCA nije pokazao terapijski benefit, već samo ozbiljnu senzo-motornu neuropatiju kao rezultat DCA terapije.

Acta Medica Medianae 2019;58(1):102-105

Ključne reči: folikularni limfom, dihloracetat, neuropatija 